\title{
Genetic Engineering, Applied
}

National Cancer Institute

\section{Source}

National Cancer Institute. Genetic Engineering, Applied. NCI Thesaurus. Code C19188.

Genetic eng ineering performed with the object of creating, modifying or otherwise enhancing a product whose manufacture is partly or entirely dependent on a biological process. 